\title{
KEBUTUHAN PERAWATAN GIGI DAN MULUT PADA PASIEN LANSIA DI POLIKLINIK PERTAMEDIKA BEKASI PERIODE JANUARI - MARET TAHUN 2020
}

\begin{tabular}{|c|c|}
\hline \multicolumn{2}{|c|}{$\begin{array}{l}\text { N. Eros Rosidah }{ }^{1} \text {, Siti Nurbayani }{ }^{2} \text {, Adelina Barus², Rizki Sofian², Tedi Purnama² } \\
\text { 1Poliklinik Pertamedika Bekasi, Indonesia } \\
{ }^{2} \text { Jurusan Keperawatan Gigi, Politeknik Kesehatan Kemenkes Jakarta I, Indonesia }\end{array}$} \\
\hline Info Artikel & Abstrak \\
\hline $\begin{array}{l}\text { Submitted: } 1 \text { April } 2020 \\
\text { Revised: } 3 \text { April } 2020 \\
\text { Accapted: } 5 \text { April } 2020\end{array}$ & $\begin{array}{l}\text { Latar Belakang: Masalah kesehatan gigi yang paling menonjol di Indonesia adalah masalah } \\
\text { kehilangan gigi akibat karies gigi. Dimana salah satu kelompok rentan terhadap penyakit gigi } \\
\text { adalah lansia. prevalensi karies gigi kelompok umur } 55-64 \text { tahun sebesar } 96,8 \% \text { dengan indeks } \\
\text { DMF-T 12,6 dan prevalensi penyakit periodontal sebesar } 79,5 \% \text { serta prevalensi kehilangan gigi } \\
\text { sebesar } 70,2 \% \text {, artinya lansia memiliki tingkat kebutuhan yang tinggi dalam perawatan gigi. } \\
\text { Tujuan: Tujuan penelitian ini adalah untuk mengetahui gambaran kebutuhan perawatan gigi dan } \\
\text { mulut pada pasien lansia di Poliklinik Pertamedika Bekasi periode Januari - Maret tahun } 2020 \text {. } \\
\text { Metode: Penelitian ini menggunakan metode deskriptif dengan sampel penelitian menggunakan } \\
\text { teknik total sampling sebanyak } 66 \text { responden. Data yang digunakan yaitu data sekunder yang } \\
\text { diambil dari rekam medis pasien. Hasil: Dari hasil penelitian diperoleh sebagian besar pasien } \\
\text { lansia Poliklinik Pertamedika Bekasi di Poliklinik Pertamedika Bekasi berjenis kelamin } \\
\text { perempuan sebayak } 36 \text { orang (54.5\%) dan berusia } \geq 60 \text { tahun } 41 \text { orang (60.6\%). Kebutuhan } \\
\text { perawatan gigi dan mulut berdasarkan perceived need pada pasien lansia adalah penambalan } \\
\text { sebanyak } 36 \text { orang ( } 56.1 \%) \text { dan kebutuhan perawatan gigi dan mulut berdasarkan evaluated } \\
\text { need pada pasien lansia adalah tindakan ekstraksi } 33 \text { orang ( } 48.5 \%)\end{array}$ \\
\hline
\end{tabular}

\section{DENTAL AND MOUTH CARE NEEDS IN ELDERLY PATIENTS IN PERTAMEDIKA POLYCLINIC BEKASI PERIOD JANUARY - MARCH 2020}

\begin{tabular}{|c|c|}
\hline Keywords: & Abstract \\
\hline Dental and Mouth Care & Background: The most prominent dental health problem in Indonesia is the problem of tooth \\
\hline Needs, Elderly & $\begin{array}{l}\text { loss due to dental caries. Where one of the groups vulnerable to dental disease is the elderly. } \\
\text { the prevalence of dental caries in the } 55-64 \text { years age group is } 96.8 \% \text { with the DMF-T index } \\
12.6 \text { and the periodontal disease prevalence is } 79.5 \% \text { and the prevalence of tooth loss is } 70.2 \% \text {, } \\
\text { meaning that the elderly have a high level of need in care tooth. Objective: The purpose of this } \\
\text { study was to determine the description of dental and oral care needs in elderly patients in the } \\
\text { Pertamedika Bekasi Polyclinic for the period January - March } 2020 \text {. Method: This study used } \\
\text { a descriptive method with a research sample using a total sampling technique of } 66 \text { respondents. } \\
\text { The data used are secondary data taken from the patient's medical record. Results: From the } \\
\text { results of the study, the majority of elderly patients in the Bekasi Medical Clinic at the Pertamina } \\
\text { Medical Clinic in Bekasi were } 36 \text { women (54.5\%) and aged } \geq 60 \text { years } 41 \text { people (62.1\%). } \\
\text { Dental and oral care needs based on perceived need in elderly patients is patching as many as } \\
36 \text { people (54.5\%) and dental and oral care needs based on evaluated needs in elderly patients } \\
\text { is extraction measures } 33 \text { people (50\%) }\end{array}$ \\
\hline
\end{tabular}

Korespondensi Penulis:

Tedi Purnama

Jl. Wijaya Kusuma No. 47-48 Cilandak Jakarta Selatan

email: tedypurnama23@yahoo.com

(C) Jurusan Keperawatan Gigi Poltekkes Kemenkes Jakarta I Jl. Wijaya Kusuma No. 47-48 Cilandak Jakarta Selatan, Indonesia email: jdht@poltekkesjakarta1.ac.id 


\section{Pendahuluan}

Undang - undang nomor 36 tahun 2009 tentang Kesehatan di pasal 93 disebutkan bahwa pelayanan kesehatan gigi dan mulut dilakukan untuk memelihara dan meningkatkan derajat kesehatan masyarakat dalam bentuk peningkatan kesehatan gigi, pencegahan penyakit gigi, pengobatan penyakit gigi dan pemulihan kesehatan gigi oleh pemerintah pusat, pemerintah daerah, dan/atau masyarakat yang dilakukan secara terpadu, terintegrasi dan berkesinambungan. Pasal 94 dijelaskan bahwa pemerintah dan pemerintah daerah wajib menjamin ketersediaan tenaga, fasilitas pelayanan, alat dan obat kesehatan gigi dan mulut dalam rangka memberikan pelayanan kesehatan gigi dan mulut yang aman, bermutu, dan terjangkau oleh masyarakat (Kemenkes RI, 2012).

Kesehatan gigi merupakan bagian intergral dari kesehatan secara keseluruhan yang dapat mempengaruhi kualitas hidup (Purnama dkk, 2019). Prevalensi karies gigi dan penyakit periodontal tinggi di masyarakat mempunyai dampak yang luas, yaitu gangguan pada kualitas hidup antara lain keterbatasan fungsi, disabilitas fisik, ketidak nyamanan psikis dan disabilty psikis. WHO pada tahun 2003 telah membuat acuan Global Goals for Oral Health 2020, yaitu meminimalkan dampak dari penyakit mulut dan kraniofasial dengan menekankan pada upaya promotif dan mengurangi dampak penyakit sistemik yang bermanifestasi di rongga mulut dengan diagnosa dini, pencegahan dan manajemen yang efektif untuk penyakit sistemik (Kemenkes, 2012).

Masalah kesehatan gigi yang paling menonjol di Indonesia adalah masalah kehilangan gigi akibat karies gigi. Penyakit karies gigi banyak dialami oleh $90 \%$ masyarakat Indonesia (Notohartojo, 2011). Dimana salah satu kelompok rentan terhadap penyakit gigi adalah lansia (Kemenkes RI, 2012). Hal ini dibuktikan hasil Riset Kesehatan Dasar tahun 2018 menunjukkan bahwa prevalensi karies gigi kelompok umur 55-64 tahun sebesar 96,8\% dengan indek DMF-T 12,6 dan prevalensi penyakit periodontal sebesar $79,5 \%$ serta prevalensi kehilangan gigi sebesar 70,2\%. Keadaan ini menunjukkan penyakit gigi dan mulut di Indonesia masih tinggi dan kebutuhan akan perawatan gigi penduduk Indonesia (dental treatment needs) masih besar (Herwanda dkk, 2014).

(C) Jurusan Keperawatan Gigi Poltekkes Kemenkes Jakarta I Jl. Wijaya Kusuma No. 47-48 Cilandak Jakarta Selatan, Indonesia email: jdht@poltekkesjakarta1.ac.id
Kesehatan rongga mulut memegang peranan penting dalam mendapatkan kesehatan umum dan kualitas hidup lansia. Keadaan mulut yang buruk misalnya banyaknya gigi yang hilang dan tidak dirawat akan mengganggu fungsi dan aktivitas rongga mulut (Sari dkk, 2015). Penelitian Puspitasari (2017) membuktikan bahwa terdapat hubungan antara kesehatan mulut dengan kualitas hidup lansia. Hal ini diakibatkan kemunduran kondisi fisiologis, obatobatan dan tingginya kejadian penyakit kronis pada lansia dapat bermanifestasi dalam rongga mulut dan mempengaruhi fungsinya (Ariela dan Fitra, 2019).

Lansia merupakan istilah bagi orang-orang yang mengalami masalah secara fisik, biologik, psikologik dan sosial, hal ini disebabkan terjadinya perubahan perubahan di dalam struktur, fungsi sel, jaringan serta sistem organ tubuh manusia (Hutauruk dan Paulina, 2017). Di Indonesia, pada tahun 2010 mempunyai populasi lansia dengan usia diatas 60 tahun keatas sebanyak 9,77\% dan pada tahun 2020 sebanyak 11,34\% (Sari dkk, 2015).

Upaya yang dilakukan untuk mengatasi masalah penyakit gigi dan mulut pada lansia yakni dengan melakukan pendekatan dari tenaga kesehatan maupun dokter gigi berupa pelayanan kesehatan gigi dan mulut (Ermawati dkk, 2015). Namun kemampuan dan kemauan penduduk Indonesia untuk memeriksakan gigi atau merawat giginya masih rendah. Angka yang menunjukkan persentase Persentase nasional Performed Treatment Index/PTI (untuk mengetahui kemampuan dan kemauan masyarakat dalam menangani perawatan karies) tahun 2013 sebesar 2,7\% (Riskesdas, 2013)

Kebutuhan perawatan dipengaruhi oleh berbagai faktor predisposisi, salah satunya adalah faktor usia. Kelompok usia yang berbeda, memiliki jenis dan jumlah penyakit yang berbeda sehingga perawatan yang dibutuhkan setiap kelompok usia juga berbeda (Herwanda dkk, 2014). Kebutuhan perawatan gigi dapat dilihat melalui perceived need yaitu kebutuhan perawatan menurut persepsi individu dan evaluated need yaitu kebutuhan perawatan yang ditentukan menurut pemeriksaan klinis.

Lansia memiliki tingkat kebutuhan yang tinggi dalam perawatan gigi hal ini sesuai dengan penelilitian Herwanda dkk tahun 2014 diperoleh perceived need 
berupa pencabutan $25 \%$, tambal $12,5 \%$, gigi palsu $18,8 \%$, keluhan lain $3,1 \%$, dan tidak membutuhkan perawatan $40 \%$. Kebutuhan perawatan berdasarkan evaluated need berupa gigi tiruan $100 \%$, ekstraksi $75 \%$, restorasi $62,5 \%$ dan perawatan periodontal $59,4 \%$.

Poliklinik Pertamedika Bekasi merupakan klinik pratama dibawah Rumah Sakit Pertamina Jaya yang melayani pasien umum dan BPJS. Pasien umumnya adalah lansia yang merupakan pensiunan dari Pertamina. Hasil data rekam medik pada bulan Januari 2020 menunjukkan pasien lansia sebanyak 168 orang dan 42 pasien lansia berobat ke klinik gigi.

Berdasarkan latar belakang di atas penulis tertarik untuk melakukan penelitian dengan judul "Gambaran kebutuhan perawatan gigi dan mulut pada pasien lansia di Poliklinik Pertamedika Bekasi periode Januari Maret tahun 2020"

\section{Metode}

Jenis penelitian ini menggunakan metode penelitian deskriptif yaitu mengetahui gambaran kebutuhan perawatan gigi dan mulut pada pasien lansia di Poliklinik Pertamedika Bekasi periode Januari - Maret tahun 2020. Populasi dalam penelitian ini adalah seluruh pasien lansia di melakukan perawatan gigi di Poliklinik Pertamedika Bekasi periode Januari - Maret 2020 sebanyak 66 orang. Teknik pengambilan sampel menggunakan total sampling yaitu seluruh populasi menjadi sampel, jadi sampel penelitian ini sebanyak 66 orang. Penelitian ini menggunakan data sekunder yang diambil dari rekam medis lansia yang telah melakukan perawatan gigi periose bulan Januari - Maret 2020, kemudian dicatat menggunakan lembar rekapitulasi yang telah ditentukan oleh peneliti. Penelitian ini diolah dan dianalisa dalam program excel dan disajikan dalam bentuk distribusi frekuensi.

\section{Hasil}

Hasil pengumpulan data karakteristik responden didapatkan bahwa responden didominasi oleh jenis kelamin perempuan sebanyak 36 orang (54.5\%) dan berusia $\geq 60$ tahun sebanyak 41 orang $(62.1 \%)$. Lebih jelasnya terdapat pada tabel 1 berikut ini:
Tabel 1. Distribusi frekuensi karakteristik responden

\begin{tabular}{ccc}
\hline Variabel & Jumlah & Persentasi (\%) \\
\hline Jenis Kelamin & & \\
Laki-laki & 30 & 45.5 \\
Perempuan & 36 & 54.5 \\
Usia Lansia & & \\
45 sd 59 tahun & 25 & 37.9 \\
$\geq 60$ tahun & 41 & 62.1 \\
\hline
\end{tabular}

Tabel 2. Distribusi frekuensi kebutuhan perawatan gigi dan mulut pada lansia berdasarkan perceived need

\begin{tabular}{ccc}
\hline Perceived Need & Jumlah & Persentasi (\%) \\
\hline Pencabutan & 19 & 28.8 \\
Penambalan & 36 & 54.5 \\
Gigi palsu & 6 & 9.1 \\
Keluhan lain & 5 & 7.6 \\
\hline Jumlah & 66 & 100 \\
\hline
\end{tabular}

Tabel 2 menunjukkan bahwa responden yang menyatakan kebutuhan perawatan gigi berupa pencabutan sebanyak 19 orang (28.8\%), penambalan sebanyak 36 orang $(54.5 \%)$, gigi palsu sebayak 6 orang $(9.1 \%)$ dan keluhan lain seperti karang gigi, gingivitis dll sebanyak 5 orang $(7.6 \%)$

Tabel 3. Distribusi frekuensi kebutuhan perawatan gigi dan mulut pada lansia berdasarkan evaluated need

\begin{tabular}{ccc}
\hline Evaluated Need & Jumlah & Persentasi (\%) \\
\hline Ektraksi & 33 & 50 \\
Restorasi & 21 & 31.8 \\
Gigi tiruan & 8 & 12.1 \\
Perawatan & 4 & 6.1 \\
periodontal & & 100 \\
\hline Jumlah & 66 &
\end{tabular}

Tabel 3 menunjukkan bahwa responden dengan kebutuhan perawatan berdasarkan tindakan klinis berupa ekstraksi sebanyak 33 orang (50\%), tindakan restorasi sebanyak 21 orang (31.8\%), tindakan pembuatan gigi tiruan sebanyak 8 orang $(12.1 \%)$ dan perawatan periodontal sebanyak 4 orang $(6.1 \%)$ 


\section{Pembahasan}

Lansia merupakan kelompok usia dengan berbagai masalah kesehatan, baik secara umum maupun rongga mulut. Masalah kesehatan rongga mulut yang paling sering diderita lansia adalah karies, kehilangan gigi dan penyakit periodontal. Keadaan tersebut menunjukan tingginya kebutuhan perawatan gigi dan mulut pada lansia. Kebutuhan perawatan dapat berupa perceived need oleh individu berdasarkan wawancara/anamnesa yang tetulis di rekam medik dan evaluated need didapat melalui pemeriksaan klinis yang terdapat dalam rekam medik untuk mengetahui kebutuhan terhadap perawatan gigi dan mulut yang meliputi perawatan konservasi, ekstraksi, perawatan periodontal, dan gigi tiruan.

Pada penelitian ini menunjukkan bahwa distribusi subjek penelitian berdasarkan jenis kelamin yaitu sebanyak 36 orang $(54.5 \%)$ merupakan perempuan dan sebanyak 30 orang $(45.5 \%)$ merupakan laki-laki. Persentase tersebut menunjukkan bahwa jumlah subjek perempuan lebih banyak daripada laki-laki. Penelitian ini serupa dengan penelitian yang dilakukan oleh Surb dan Evans (2001) yang menyatakan bahwa subjek terbanyak adalah perempuan dengan total 140 subjek (80\%) dibandingkan dengan laki-laki sebanyak 35 subjek (20\%) dikarenakan perempuan secara umum lebih peduli dengan keadaan gigi dan mulut serta perawatan terkait estetik daripada laki-laki.

Hasil dari penelitian ini yang dilakukan kepada 66 subjek berdasarkan kelompok usia menunjukan bahwa 25 orang (37.9\%) adalah pralansia dan sebanyak 41 orang $(62.1 \%)$ adalah lansia. Keadaan ini menunjukkan bahwa subjek penelitian lebih didominasi oleh pasien lansia daripada pralansia. Hal tersebut dikarenakan lansia lebih cenderung berusaha untuk mendapatkan perawatan gigi mulut.

Kebutuhan perawatan gigi dan mulut berdasarkan perceived need menunjukkan yang paling banyak adalah penambalan sebanyak 36 orang (54.5\%), dan paling sedikit berupa keluhan lain seperti karang gigi, gingivitis dll sebanyak 5 orang (7.6\%). Keadaan tersebut dikarenakan pasien memperoleh informasi dan memiliki pengetahuan tentang kondisi kesehatan rongga mulut sehingga timbul pertanyaan(C) Jurusan Keperawatan Gigi Poltekkes Kemenkes Jakarta I J1. Wijaya Kusuma No. 47-48 Cilandak Jakarta Selatan, Indonesia email: jdht@poltekkesjakarta1.ac.id pertanyaan terkait perawatan yang berhubungan dengan kondisi rongga mulut mereka. Hal ini tidak jauh berbeda dengan hasil penelitian Fadilah dkk (2011), diperoleh 286 karyawan Perum Damri Bandung yang mengalami kerusakan gigi 97.9\% (280 orang) yang paling banyak adalah gigi berlubang. Kebutuhan perawatan gigi yang paling banyak dibutuhkan adalah tumpatan yaitu sebanyak 266 orang (93.01\%).

Pada penelitian ini kebutuhan perawatan menurut evaluated need didominasi oleh kebutuhan perawatan gigi berupa ekstraksi 33 orang (50\%) dikarenakan kondisi rongga mulut lansia di Poliklinik Pertemedika Bekasi sebagian besar berupa radiks akibat karies yang tidak ditangani. Hal ini didukung oleh penelitian relevan yang dilakukan oleh Herwanda dkk (2014). Hasil penelitian kebutuhan perawatan evaluated need menyatakan bahwa $75 \%$ ekstraksi, $62.5 \%$ restorasi, $54.9 \%$ perawatan periodontal. Karies merupakan masalah gigi dan mulut yang menyebabkan tingginya persentase pencabutan gigi. Karies adalah masalah yang sering ditemukan pada lansia yang dipengaruhi oleh kebiasaan makan, status nutrisi dan kesehatan rongga mulut.

Hasil penelitian di atas jika dibandingkan kebutuhan perawatan gigi dan mulut antara perceived need dan evaluated need menunjukkan kesesuaian/ persamaan sebesar $74.2 \%$. Sedangkan perbedaannya hanya $25.8 \%$. Maka bisa diartikan bahwa sebagian besar presepsi perawatan yang akan diharapkan pasien sesuai dengan tindakan klinis yang dilakukan.

\section{Kesimpulan dan Saran}

Berdasarkan hasil penelitian, dapat disimpulkan bahwa:

1. Diketahui sebagian besar pasien lansia di Poliklinik Pertamedika Bekasi periode Januari - Maret 2020 berjenis kelamin perempuan 36 orang $(54.5 \%)$ dan berusia $\geq 60$ tahun 41 orang $(62,1 \%)$.

2. Diketahui sebagian besar kebutuhan perawatan gigi dan mulut berdasarkan perceived need pada pasien lansia di Poliklinik Pertamedika Bekasi periode Januari - Maret 2020 adalah penambalan sebanyak 36 orang $(54,5 \%)$ 
3. Diketahui sebagian besar kebutuhan perawatan gigi dan mulut berdasarkan evaluated need pada pasien lansia di Poliklinik Pertamedika Bekasi periode Januari - Maret 2020 adalah tindakan ekstraksi 33 orang $(50 \%)$

Sehubungan dengan hasil penelitian maka dapat disarankan sebagai berikut:

1. Diharapkan bagi pasien lansia untuk menjaga kesehatan gigi dan mulut, sehingga dapat meminimalkan terjadinya masalah gigi dan mulutnya serta lansia yang dilakukan tindakan pecabutan gigi diharapkan untuk memakai gigi palsu agar pengunyahan tetap baik dan optimal.

2. Disarankan untuk penelitian selanjutnya mengenai kebutuhan perawatan gigi dan mulut pada pasien usia remaja dan dewasa muda agar dapat dijadikan perbandingan dengan kelompok lansia

\section{Daftar Pustaka}

Ariela, Fitra A (2019). Pengaruh Status Kesehatan Gigi Lansia Terhadap Kualitas Hidup di UPT Pelayanan Sosial Lanjut Usia Binjai. Naskah Publikasi. Universitas Sumatera Utara.

Evan R, Saub R (2001). Dental Need of Elderly Hostel Resident in Inner Melbourne. Australian Dental Journal. 46:198-202

Ermawati T, Sari SD, Yuliana MDA (2015). Upaya Peningkatan Kesehatan Gigi Dan Mulut Pada Lansia (Improving The Oral Health Of Elderly). Naskah Publikasi. Fakultas Kedokteran Gigi, Universitas Jember

Fadilah NR. Putri, Susilawati S, Soetardjo D (2011). Status Kesehatan Gigi dan Kebutuhan Perawatan Gigi Pada Karyawan Perum Damri Bandung. Naskah Publikasi. Fakultas Kedokteran Program Studi Kesehatan Masyarakat Universitas Padjadjaran.

Herwanda, Liana R, Sari N (2014). Gambaran Kebutuhan Perawatan Gigi Dan Mulut Pada Pasien Di Posyandu Lansia Puskesmas. Cakradonya Dent J 2014; 6(1):619-677
Hutauruk, Paulina D (2017) Kebutuhan Perawatan Periodontal pada Lansia di Kecamatan Medan Baru. Naskah Publikasi. Universitas Sumatera Utara.

Kementerian Kesehatan Republik Indonesia (2012). Pedoman Paket Dasar Pelayanan Kesehatan Gigi Dan Mulut di Puskesmas. Direktorat Jenderal Bina Upaya Kesehatan, Jakarta.

Kementerian Kesehatan Republik Indonesia (2012). Usaha Kesehatan Gigi Sekolah (UKGS), Direktorat Jenderal Bina Upaya Kesehatan, Jakarta.

Kementerian Kesehatan Republik Indonesia (2018). Riset Kesehatan Dasar. Badan Penelitian dan Pengembangan, Jakarta

Kementerian Kesehatan Republik Indonesia (2013). Riset Kesehatan Dasar. Badan Penelitian dan Pengembangan, Jakarta

Nidyawati N, Wicaksono AD, Joenda SS (2013). Gambaran Tingkat Pengetahuan dan Kebersihan Mulut Pada Masyarakat Lanjut Usia di Kelurahan Rurukan Kecamatan Tomohon Timur. Jurnal Biomedik (JBM): Volume 5, Nomor 1, Suplemen, Maret 2013, hlm. 169-174

Notohartojo TI, Made LS, Woro R, Olwin N (2011). Nilai Karies Gigi Pada Karyawan Kawasan Industri Di Pulo Gadung Jakarta, Media Litbang Kesehatan Volume 21 Nomor 4 Tahun 2011

Puspitasari B (2017). Hubungan Kesehatan Mulut Dengan Kualitas Hidup Lansia Di Puskesmas Pajang Surakarta. Naskah Publikasi. Program Studi Keperawatan Fakultas Ilmu Keperawatan Universitas Muhammadiyah Surakarta

Purnama T, Rasipin R, Santoso B. (2019). Pengaruh Pelatihan Tedi's Behavior Change Model pada Guru dan Orang Tua terhadap Keterampilan Menggosok Gigi Anak Prasekolah. Jurnal Quality Kesehatan. 13(2):75-81.

Sari SD, Arina MD, Ermawati T (2015) Hubungan Pengetahuan Kesehatan Gigi Mulut Dengan Status Kebersihan Rongga Mulut Pada Lansia. Jurnal IKESMA: Volume 11 Nomor 1 Maret 2015 